\title{
EUROPEAN PERSPECTIVE ON ENVIRONMENTAL LIABILITY FOR INJURY
}

\author{
Mihai Dorel Vlad \\ Faculty of Juridical and Administrative Sciences \\ "Dimitrie Cantemir" Christian University, Bucharest, Romania \\ *Correspondence: Mihai Dorel Vlad, "Dimitrie Cantemir" Christian University, \\ 176 Splaiul Unirii, 4th District, Bucharest, Romania \\ E-mail: vladmdore1@yahoo.com
}

M. D. Vlad

\begin{abstract}
As is known, pollution (in all its forms) is most often a latent threat, particularly serious. It is not, as a rule, a sudden event, but is the result of slow accumulation of negative effects, which, unchecked and unrepaired timely touch time limits that exceed natural levels of balance, causing extremely dangerous consequences for the existence and functioning naturally.
\end{abstract}

Keywords: pollution, environmental law, directive, pollutant

\section{Introduction}

In ecological field is particularly important to ensure in all cases reparation due to specific and very serious consequences that may generate losses. National interest nature of environmental protection and enhancement and other relevant considerations outlined above have imposed liability so as to adopt a more secure system that would provide full compensation, effective and, if possible, the nature of the damage caused to the environment.

Through environmental and collective interests are affected thereby indirectly, for which repair could not be adequately covered in terms of classical law, which involves damage to individual interests clearly identified. In 1972 the right to a healthy environment was enshrined in the Declaration of Stockholm3 in Principle 1: "Man has the fundamental right to freedom, equality and satisfactory living conditions, in a quality which enables him to live in dignity and prosperity. He has the sacred duty to protect and improve the environment for present and future generations".

European Convention on Human Rights does not have a text itself to guarantee the right to a healthy environment.

Countries have adopted an Additional Protocol providing the right environment and, as was the case of other fundamental rights such as the right to property, education, free, to not be tried twice for the same offense, etc.., although a draft additional protocol was prepared by Professor Steiger since 1973.

Tried also protecting the right to a healthy environment in the scope of art. 6 European Convention on Human Rights. Thus, in 1993 because Zender against Sweden, the Court sanctioned the violation of those saying that a well water pollution as a result of prejudice landfill ownership and im prejurarea that the applicants had no opportunity to challenge the decision in court management led to the conviction of Sweden.

In accordance with the "polluter pays" an operator causing environmental damage or creating an imminent threat of such damage should bear, in principle, the costs of preventive or remedial measures. Where a competent authority acts, itself or through a third party, instead of an operator, that authority should ensure that the costs it has incurred will be recovered from the operator. Also, operators should bear the ultimate cost of assessing environmental damage and, if necessary, assessing an imminent threat of such damage. People affected or likely to be affected by environmental damage should be entitled to request 
the competent authority to take action. However, environmental protection is a diffuse interest that individuals always act or are not always able to act.

Subjective liability based on fault who committed tort, negligence to be proven by the victim. In our civil code, article 998 and 999, the entire one another, based solely on its liability and the negligence or intentional negligence.

Liability for damages appears to be based on breach of statutory duty for all individuals and businesses to protect the environment. That does not mean, however, an exception to the general principle that anyone who causes injury should fix it. What will make this specific responsibilities, as we shall see below, there are conditions and how liability for compensation from the point of view of the author and establish victim entitled to compensation.

Given the peculiarities of the domain, there can be no certainty about causality and ought to accept the existence of one eminently probable. Then there is the issue of the measure, which must take into account all the elements in this, so you need not reach its negation, but not a high certainty, so is an offense and shall be punished accordingly, breaching obligations of natural and legal to bear the cost of compensation for damage and remove the consequences of this damage occurred restoring previous conditions, according to the "polluter pays" [Art. 96 para. (3) Section 14 of Ordinance no. 195/2005] or corporate obligations to cover the costs of measures to prevent and/or reduce the adverse consequences of the activities that genetic organisms [art. 96 para. (3) Section 10].

In environmental law is often used in administrative responsibility (against conventional) to prevent or combat non statutory requirements. Procedure for the determination and application of administrative sanctions is much faster and more flexible in relation to other legal proceedings, which is favorable repair requirements with priority environmental damage. According regulatory framework in force, by law or government decisions may determine and punish offenses in all fields, and by the decisions of local authorities or county shall be established and sanctioned offenses in all fields in which their tasks they are set by law, in so far as these areas are not established by law or by offenses Government decisions. From the point of view of environmental issues that historically the first law in the field nr.9/1973 Act established certain categories of offenses relating to various environmental factors: air, water, soil. After 1989 updating and improving the contravention in GD was performed on certain offenses nr.127/1994 environmental rules. Environmental Protection Law no.137/1995 devote a number of offenses punishable by fine.

The new regulatory framework in this area, the Government Emergency Ordinance no. $195 / 2005$ has preserved, in general, the same conception of offenses, with some adjustments on their subject and especially financial penalties apply. Criterion applicable fines in art. 96 of the Ordinance are three categories of offenses:

- Group I are 27 offenses consisting in violations of the law such as corporate obligations to perform self-monitoring systems and report the results to the competent authorities, to keep strict records of dangerous substances and preparations, identify and prevent risks they may pose to human health and the environment, the obligation to maintain alignment windbreaks and protection.

- Group II with 34 offenses, including the violations of legal provisions such: duty individuals requesting and obtaining regulatory acts, the obligation to inform the public about the risks of operating or environmental risk objectives existence.

- Group III offenses, environment, considered the worst, at least in terms of fines, including a number of 15 violations of the law, for example, individuals and legal obligation to reduce, modify or terminate generating activities pollution reasoned request from the competent authorities, natural and legal obligations to bear the cost of compensation for damage and remove the consequences of this damage occurred restoring previous conditions, according to the "polluter pays" etc.

The current regulatory framework provides not update regularly (annually) of fines. 
Passive subject of liability offenses in is undeniably the entire community, represented by the formal-legal state. Rules on the liability issue is that the individual offenses is responsible for committing the offense.

As such, it is punishable by a sanction under the law, any person, regardless of nationality or residence. The legal entity responsible contravention cases and conditions stipulated by the legislation which established and sanctioned offenses. Some additional sanctions apply only to businesses (shutting down, suspending work, etc.). Environmental offenses appear as subjects of responsibility, with individuals and businesses in general, and some situational, such as local authorities, land owners and holders of title or no title, legal and natural persons authorized etc.

Whatever the nature conferred (civil, administrative, specific contravention), the procedure involves the stages contravention contravention finding, the sanction and remedies against acts of enforcing. Ascertained and the sanctioning (fine) are persons appointed by the Commissioner and the National Guard Environmental and Biosphere Reserve "Danube Delta" specialized people of the National Commission for Nuclear Activities Control. Judgment resolving the complaint may be appealed within 15 days of communication, with the peculiarity that its motivation is not mandatory, it can be sustained and orally before the court. The appeal suspended the judgment. Crime against the environment (ecological) is becoming more profitable and therefore more intense, creating a global annual turnover estimated at between 18 and 24 billion euros, mainly through the activities of illegal storage of hazardous waste, traffic toxic substances prohibited and protected natural resource smuggling. Illicit trade from rare, endangered ensure the highest profit, constituting the second illegal market in the world after the drugs.

Globalization has been rapid and substantial benefits it brings, have expanded Environmental crime in Romania. Illegal importation of toxic, massive deforestation, irrational trade of protected species (sturgeon, game etc.) and numerous acts of pollution and environmental deterioration illicit profits for million and produce incalculable environmental damage.

Such acts are encouraged by the fact that most of them, though contrary to the law and a great social danger, remain unpunished. Among the reasons: an inadequate criminal law field and a chronic state of inefficiency in its application. Use of criminal law to protect the environment has become a rare protected traditional values, such as a personl's life or property were replaced in this case with res nullius, such as water or air, and quantifiable damage and repaired economically, diffuse, hard cash assessable. However, under pressure to adapt and juridical realities in this regard, so starting with the German law on the fight against environmental crime in 1980, environmental offenses and have appeared in criminal register. They were multiplied and diversified gradually included in special sections of the criminal code or systematized in environmental codes.

Romanian law long remained tributary system failure dependence organic criminalization of administrative obligations (subject to authorization or provided by it). Environmental promotion to the rank Attempt core values protected by criminal law offenses environmental via incorporation in even the Criminal Code (Law no. 301/2004) remained at this stage, given that its fate is uncertain, on the contrary, the new Penal Code environmental crimes in the sphere of special legislation. In these conditions, the new regulatory framework Emergency Ordinance no. 195/2005 on environmental protection, some progress, keep the major limitations in the conception and criminal environmental protection instruments. Inadequacy of the peculiarities of illicit environmental legislation is an important cause of inefficiency fight against environmental crime.

Opting for a sectorial approach, were provided crimes and offenses for violation of rules on atmosphere protection (Article 395), violation of rules on water protection (Article 396), violation of water management rules (Article 397), violation rules on the use of drinking water (art. 398), destroying water protection works (art. 399), breaking the rules on forest protection (art. 401), noise pollution (art. 402), accidental pollution (art. 403). As a particular 
legal entity shall be punished for offenses against the environment. However, the enactment failed to provide an adequate framework domain, create an ecological crime type to configure on which the whole edifice of environmental criminal. Then there are some situations where the exact setting of the author injury is impossible, and the consequences can not get covered products, moreover, can worsen if not addressed in a timely manner. It was necessary, therefore, especially in terms of pollution, as statutory provisions to ensure a complete repair, efficiency, timeliness of any damage to the environment, establish liability rule regime also allowed risk based stimulation and diligent attitude prudent, sustainable use of environmental factors, the establishment and improvement of a system of life insurance adapted to the new economic and social requirements. Consequently, in those cases in which environmental pollution is produced, and if he could identify the damage resulting in a breach of the provisions of special legislation (Law no. 9/1973, Law no. 61/1974) on the legal of responsibility, it must be found in art. 1000 par. (1) Civil Code. In favor of such a position is raised and the fact that always, environmental pollution is achieved through a thing (or a power), and according to a 1953 decision of the supreme court, the thing is any material form, including energy. In concept become classics, strict liability is based on the idea of risk, and any other activity that creates the risk, is the author or responsible for the damage it can cause, without the need to prove a culpable attitude.

Liability Risk Theory started initially with the idea of justice that any human activity follows a profit, therefore, it is reasonable that any damage you cause to be repaired (emolumentum ubi, ibi onus). Responsibility for risk brought to the environment and ecological balance - which we are (or should represent) actually specific manifestation of civil liability in organic matter - not to diminish or cancel the preventive-corrective it aims liability for negligence, this role moves significance other steps to achieve repair such damage caused. Given that pollution is caused primarily by the general activity of economic agents must therefore their liability risk, whose consequence is to be passed collectively or individually. From this perspective, retains responsibility for environmental risk and even increase their function to prevent and combat the negative effects on environmental quality.

For more exact dimensions circumstantiation such liability is required highlighting certain features of environmental risk. As is known, the risk of civil liability regime has a number of advantages, especially in organic matter in relation to liability based on fault. First, compensating the victim will always be contrary to the theory of liability for negligence, when sometimes there are cases where it can not be held liable, and accordingly, such damage product. Even exemptions from restrictive covered replied to force majeure, it's recognizing the effects of graduation in certain conditions. Within the European Union, the obligation to protect the environment and natural habitat has been stated by the Directive on the responsibility for the prevention and remedying of environmental damage. The scope, this raises the possibility that a company be held liable for damage to the environment. Its effectiveness will depend upon the quality of the infrastructure that the EU will create and use in the process of implementation (internal regulations, regulators, control devices, etc..).

Within the European Union, the obligation to protect the environment and natural habitat has been stated by the Directive on the responsibility for the prevention and remedying of environmental damage. The scope, this raises the possibility that a company be held liable for damage to the environment. Its effectiveness will depend upon the quality of the infrastructure that the EU will create and use in the process of implementation (internal regulations, regulators, control devices, etc.). EU approach will have a major impact on companies that focus on the product or its component sub-expand the circle of those who can be held liable in case of a risk event. In these circumstances, appropriate management of environmental risk requires a company to have a global vision of the life cycle of its products and operations. The Directive was implemented in Hungary, Italy, Lithuania and Latvia until 30 April 2007. Later, it was incorporated into the national legislation in 15 EU Member States, including Romania. Austria and Belgium were aligned with EU requirements by federal law, and the remaining six countries, including Britain, are to implement this Directive in no time. 
From an operational perspective, environmental risks may cause disruption of business (production of accidents, suspension or cancellation of license, etc..), With serious consequences for the company. Measures to adapt to the environment help to optimize operations and reduce the possibility of sanctions from the authorities. Reputational risk they expose a company or non-compliant practices that generate risk events is difficult to estimate the financial consequences and sustainable over time.

On the other hand, as the existing rules require effective guarantees against discrimination and discriminatory practices is absolutely necessary in a democratic society, all in this way rules governing protection of the environment are useful and also healthy.

A special case of the mergers and acquisitions transactions where the risk environment has become an item of great interest. In assessing asset entities required knowledge and careful analysis of historical practices to identify potential damage that could occur in the future, state assets (possible contamination) and how environmental risks have been transferred through insurance.

A new element introduced by the European Directive on environmental responsibility is that it extends the principle of "polluter pays" on measures to prevent and remedy environmental damage products. Another improvement is to cover new categories of damage, namely those on protected species, natural habitats, soil (significant health risks) and water (adverse effects). Taken together, the Directive focuses on preventing damage, eliminate adverse environmental effects and recovery of damaged items through rehabilitation, restoration or replacement of natural resources (including the provision of an equivalent).

\section{Conclusions}

Operator whose activity causes imminent threat to the environment shall immediately take the necessary preventive measures. If damages have already occurred by primary remedial measures must ensure resume services or restoration of natural resources in the previous condition. Where primary remediation is not possible, in the sense of full restoration of the previous situation, operators are required to act to remedy complementary. Between the time of the damage and that the primary remedy takes effect, compensatory remedial measures to be taken in order to cover the temporary loss of natural resources or services.

\section{Bibliography}

Radu, M.E., Principiul nediscriminarii in politica sociala a Uniunii Europene, captiol in Exercitarea dreptului la nediscriminare si egalitate de sanse in societatea contemporana, Pro Universitaria Publishing House, Bucharest, 2012;

Anghel, D., Răspunederea juridică privitoare la protecția mediului. Privire specială asupra răspunderii civile, Publishing House, Bucharest, 2010;

Lupan, E., Tratat de dreptul protecţiei mediului, C.H. Beck Publishing House, Bucharest, 2009;

Duţu, M., Dreptul mediului. Curs universitar, ed. a 2-a, C.H. BECK Publishing House, Bucharest, 2008;

Durac, G.; Bouriaud, L., Dreptul mediului. Răspunderea juridică pentru daune ecologice, Junimea Publishing House, Iaşi, 2004;

Steiger, H., Le droit à un environnement humain, Erich Schmidt Verlag, 1973;

Eliescu, M., Răspunderea civilă delictuală, “Academiei” Publishing House, Bucharest, 1972 ;

Raymond-Gouilloud, M., Du droit de detruire. Essai sur le droit de l'environnement, P.U.F., 1989;

Geală, A., Răspunderea pentru protecţia mediului, http://www.primm.ro/ $\underline{82 \text { raspunderea-pentru-protectia-mediului.html. }}$ 